\title{
Allometric relationships of frequently used shade tree species in cacao agroforestry systems in Sulawesi, Indonesia
}

\author{
Nina Tiralla $\cdot$ Oleg Panferov $\cdot$ Alexander Knohl
}

Received: 10 July 2012 / Accepted: 17 February 2013/Published online: 3 March 2013

(C) The Author(s) 2013. This article is published with open access at Springerlink.com

\begin{abstract}
Shade trees play an important role within agroforestry systems by influencing radiation and wind regimes as well as nutrient and hydrological cycling. However, there is a lack of quantitative assessments of their functions. One of the reasons is the rare information on structural characteristics of shade tree species. Therefore, the aim of this study is to provide basic information on the structure of frequently used shade tree species for the implementation of models simulating the ecosystem processes in agroforestry systems. The investigation of the shade trees was conducted at two cacao agroforestry sites on Sulawesi, Indonesia. The measurements of the main structural parameters: diameter at breast height, tree height, trunk height, crown length and crown radius were carried out for the shade tree species Aleurites moluccana, Cocos nucifera and Gliricidia sepium. For data collection, the National Forest Inventory Field Manual Template by FAO (2004) was applied. Based on this information allometric functions were derived for the correspondent shade tree species. The best significant relationships were obtained for the height-
\end{abstract}

N. Tiralla $(\bowtie) \cdot$ O. Panferov · A. Knohl

Department of Bioclimatology, Georg-August-Universität

Göttingen, Büsgenweg 2, 37077 Göttingen, Germany

e-mail: ninschent@hotmail.com

O. Panferov

e-mail: opanfyo@uni-goettingen.de

A. Knohl

e-mail: aknohl@uni-goettingen.de crown length relationship of the dicotyledonous tree species' A. moluccana and G. sepium with a coefficient of determination $r^{2}=0.925$ and $r^{2}=0.738$, respectively, and the height-crown length relationship of the monocotyledonous palm $C$. nucifera with $r^{2}=0.663$. The transferability tests 'analysis of covariance' and 'homogeneity of slopes' have shown that the obtained allometric functions are also applicable to other cacao agroforestry systems of the region.

Keywords Tree allometry - Aleurites moluccana . Gliricidia sepium . Cocos nucifera .

Cacao agroforestry system

\section{Introduction}

Within the context of conservation of tropical rainforests, sustainable development of rural areas and afforestation and reforestation of degraded lands, agroforestry systems have become an increasingly successful approach as they reduce pressure on natural forests while meeting economic as well as social needs of the local population (Michon and de Foresta 1996; Nair 1998; Rice and Greenberg 2000; Bhagwat et al. 2008; Jose 2009). Agroforestry systems consist of a low-density stratum of tall perennial woody plants i.e. shade trees, with a stratum of agricultural crops 
underneath, i.e. shade-bearers like cacao (Theobroma cacao), planted at the same land-management unit. Hence, an agroforestry system encompasses at least two different plant species, which allows a higher productivity and more ecological stability (Lundgren and Raintree 1982). Shade trees, which provide shade for crops underneath, are a crucial component of agroforestry systems as they modify radiation and wind regimes as well as nutrient and hydrological cycling. Biological species composition, mass balance, and productivity of agroforestry systems are influenced by intensity and distribution of shade (Beer 1987; Rice and Greenberg 2000; Mialet-Serra et al. 2001; Siebert 2002; Zuidema et al. 2005; Isaac et al. 2007). However, the impact of shade trees on cacao crops is discussed controversially as it is not yet evident in which aspects and how strong shade trees favour or hamper cacao crops (Beer 1987; Somarriba and Beer 2011; Tscharntke et al. 2011).

To address this topic, models were developed describing the cycle of organic matter and nutrients (Alpízar et al. 1986; Fassbender et al. 1988; Beer et al. 1990; Dudley and Fownes 1992; Fuwape et al. 2001; Cole and Ewel 2006; Segura et al. 2006), the hydrological cycle (Imbach et al. 1989; Roupsard et al. 2006; Köhler et al. 2009) and radiative transfer in agroforestry systems (Dauzat and Eroy 1997; MialetSerra et al. 2001; Leroy et al. 2005; Lamanda et al. 2008; Roupsard et al. 2008; Leroy et al. 2009; Quesada and Somarriba 2009). These models often require information on species-specific structural features of shade trees. For example, the model 'ShadeMotion 2.0' by Quesada and Somarriba (2009) for the simulation of shading pattern of tree shades requires information on trunk height, crown length, crown radius and crown shape to depict different tree species. Some attempts to model the structure of tropical shade tree species as Acacia mangium, Cocos nucifera and Tectona grandis were made by Leroy et al. (2009) and Dauzat and Eroy (1997).

However, the required structural parameters of shade trees are not always measurable directly. For instance, in cacao agroforestry systems, shade trees are usually growing amidst cacao plantations with their crowns above the cacao canopy. Therefore, the dense cacao canopy often obscures a direct view on their crown. Standard measurement techniques used in forest inventories presuppose a more or less unobstructed view on a tree or at least the part of the tree, which should be measured (e.g. crown base). Hence, measurements in at least two-storied cacao agroforestry systems by means of standard inventory practices are often impossible for parameters containing crown elements. In such cases, the most facilely accessible parameter to measure is diameter at breast height (dbh).

Therefore, species-specific allometric functions between different structural parameters are a useful tool allowing the deduction of inaccessible structural characteristics like height, crown length and crown radius from known or more easily measurable ones as $\mathrm{dbh}$. However, information about structural features of tropical tree species and their relations is rare (Thiollay 1995; Le Roux and Sinoquet 2000; Muñoz et al. 2006).

In Indonesian agroforestry systems, the typical shade tree species are, inter alia, Gliricidia sepium, Erythrina spp., Inga spp., C. nucifera, Aleurites moluccana and Durio zibethinus (Clough et al. 2009; Stenchly et al. 2012). They serve the purpose of shade and shelter, soil protection and fertilizer, pest and disease control, crop health and economically and biologically enriched fallows (Beer 1987; Rice and Greenberg 2000; McNeely and Schroth 2006; Isaac et al. 2007).

The aim of this study is, therefore, to provide basic information on species-specific tree structural parameters of frequently used shade tree species in Indonesian cacao agroforestry systems and to develop allometric relationships for the implementation in ecological investigations dealing with agroforestry ecosystem processes. Special attention is given to relationships between easily measurable parameters, e.g. dbh, and parameters, which are more difficult to measure in dense cacao stands, e.g. crown radius. The transferability of the obtained allometric relationships to other agroforestry systems of that region is investigated.

\section{Materials and methods}

Study sites

Data collection was conducted in two cacao agroforestry sites in the villages Omu $\left(1^{\circ} 17^{\prime} 6.7^{\prime \prime} \mathrm{S}, 119^{\circ} 56^{\prime} 51.2^{\prime \prime} \mathrm{E}\right.$, $188 \mathrm{~m}$ a.s.1.), subdistrict Kecamatan Kulawi, and Bulili $\left(1^{\circ} 10^{\prime} 24.3^{\prime \prime} \mathrm{S}, 120^{\circ} 5^{\prime} 31.7^{\prime \prime} \mathrm{E}, 588 \mathrm{~m}\right.$ a.s.l.), subdistrict Kecamatan Palolo, located in Central Sulawesi, Indonesia. Both sites are situated in a highly heterogeneous 
agricultural landscape with diverse small-scale land-use systems varying between wet-field agriculture, slashand-burn cultivation and agroforestry systems in the rainforest fringe area along Lore Lindu National Park. The study site Omu is a two-storied plantation with C. nucifera in the upper layer and cacao underneath whereas the study site Bulili is a cacao plantation with a mixture of G. sepium, C. nucifera, A. moluccana, Durio zibethinus and Persea americana as shade trees. Here, the crown of G. sepium was laterally pruned, implying a reduction of crown radius, after the trunk reached a dbh of about $20 \mathrm{~cm}$. More precise statements about pruning frequency and intensity could not be provided by the farmers.

The spatial transferability of functions obtained for Omu and Bulili was tested using inventory data collected in the course of studies in 21 cacao plantations distributed throughout the Kecamatan Kulawi and Kecamatan Palolo (data: Yann Clough, Universty of Göttingen, Germany, and Ramadhanil Pitopang, Tadulako University, Indonesia, pers. com.). Only plantations containing the respective shade tree species were selected for the test of transferability. Plantations with at least 15 trees per species were considered individually, all other plantations (with fewer shade trees per plantation) were combined into one 'plantation' called after the valley (Kulawi and/or Palolo) in which the combined plantations are situated. For these plantations, data about the establishment and tending techniques of the shade tree layer are not available, therefore, it is not known if shade trees are naturally grown rainforest remnants or were planted artificially.

\section{Shade tree species}

The shade tree species A. moluccana (L.) Willd., $C$. nucifera (L.) and G. sepium (Jacq.) Walp. are selected as objects of study due to their high incidence among the cacao agroforestry systems of the study region and their ecological and economical importance for these systems. All three shade tree species are light demanders and their application in agroforestry systems comprises shade and shelter, soil improvement and stabilisation, windbreak and silvopasture (Simons and Stewart 1998; Elevitch 2006; Orwa et al. 2009).

Aleurites moluccana (L.) Willd. (Euphorbiaceae), native to Indonesia, is particularly suitable for agroforestry systems since it is a very tolerant regarding poor soils, drought and wind, and it has a natural defence against insects and rodents, as all components of the tree are toxic (Barwick 2004; Elevitch 2006; Orwa et al. 2009). The appearance of this evergreen deciduous tree is bulky with a sprawling crown (Stuppy et al. 1999; Lo Gullo et al. 2005; Elevitch 2006; Chen et al. 2009). In the open, A. moluccana has a low crown base and naturally grows up to $20 \mathrm{~m}$ height with a crown diameter of 10-15 m with wide protruding or pendulous branches and foliage almost to the ground (Barwick 2004; Elevitch 2006; Orwa et al. 2009). In dense stands, it has tall and mostly branchless trunks. The 'Direktorat Hutan Tanaman Industri' (1990) in Indonesia even mentioned a tree height of up to $35 \mathrm{~m}$, with a branchless bole of $10-14 \mathrm{~m}$ and a trunk diameter of up to $1 \mathrm{~m}$. The palmately lobed silvery leaves are up to $30 \mathrm{~cm}$ long (Barwick 2004). It is assumed that A. moluccana is a moderately fast growing tree species with a growth rate of $0.5-1.5 \mathrm{~m}$ in height per year; young trees can grow 1-2 $\mathrm{m}$ in height per year, whereas, for older trees, the growth rate will decline over the years. However, direct information about the growth and development of A. moluccana is very limited (Elevitch 2006).

Cocos nucifera (L.) (Arecaceae), a palm native to Indonesia, necessarily requires full sun but tolerates saline and infertile soils. This tolerance combined with specific crown morphology makes cocos very suitable for agroforestry systems (Menon and Pandalai 1958; Lotschert 1985; Elevitch 2006; Orwa et al. 2009). The trunk, which appears after 3-4 years of growth under the crown, will not grow wider once it is formed. The dbh of the palm is predetermined by the width of the apical meristem, which is dependent on the genetic information as well as on light, water, and nutrient supply. Since the trunk of $C$. nucifera is formed as a result of leaf replacement when lignification of the older parts of the shoot apex takes place, a continuous growth in length of the trunk occurs (Lotschert 1985; Elevitch 2006). Thus, it resembles a tall, uniformly thick, unbranched pillar (Menon and Pandalai 1958; Henderson 2009). Therefore, the tree age can be roughly estimated from the length of the trunk (Elevitch 2006). The evergreen $C$. nucifera reaches a height of 20-22 $\mathrm{m}$ at the age of 40 years and of $35-40 \mathrm{~m}$ at the age of 80 years and has a trunk diameter of 30-40 cm (Elevitch 2006; Henderson 2009; Orwa et al. 2009). The branchless terminal 
crown consists of 30-40 pinnate leaves (Menon and Pandalai 1958; Elevitch 2006), also called fronds, each up to $6 \mathrm{~m}$ long (Menon and Pandalai 1958; Lotschert 1985), which are arranged in five spirals wherein the angle of deflection of successive fronds ranges from $137^{\circ}-141^{\circ}$ (Menon and Pandalai 1958). Cocos nucifera is a moderate growing species, which shows the most rapid growth between the second and fifth year. Until the age of 40 years, it grows $30-50 \mathrm{~cm}$ per year in height; thereafter, the growth rate declines (Elevitch 2006).

Gliricidia sepium (Jacq.) Kunth ex Walp. (Fabaceae) is an invasive tree legume in Indonesia that often serves as erosion control, living fence post and pest control (Simons and Stewart 1998; Barwick 2004; Elevitch 2006; Orwa et al. 2009). Gliricidia sepium tolerates drought, wind, and slightly saline calcareous soils. Combined with the ability to propagate easily from both seeds and cuttings and its toxic bark, roots and seeds as natural defence against rodents, it makes the gliricidia a very suitable plant for agroforestry systems (Barwick 2004; Elevitch 2006). As evergreen semi-deciduous tree legume, it is nitrogen-fixing due to its symbiotic relationship with rhizobia (Simons and Stewart 1998; Elevitch 2006). Gliricidia sepium naturally grows up to $15 \mathrm{~m}$ height whereas the common height is about 10-12 m (Simons and Stewart 1998; Elevitch 2006; Orwa et al. 2009). The trunk may be single or multistemmed (Orwa et al. 2009) whereas no aligned statements about the diameter were made; it varies between 20 to $30 \mathrm{~cm}$ (Elevitch 2006) and 50-70 cm (Simons and Stewart 1998; Suttie 2011). Naturally, the crown of G. sepium is up to $10 \mathrm{~m}$ in width and often diffusely and irregularly shaped with pinnate leaves of 15-30 cm length (Barwick 2004; Elevitch 2006). However, in agroforestry systems the size of G. sepium crowns is usually controlled by correctional prunings, whereas pruning intensity, technique, and frequency differ strongly (Barwick 2004; Elevitch 2006; Orwa et al. 2009). Gliricidia sepium is a fast growing species with growth rate up to $3 \mathrm{~m}$ in height during the first year whereas it decelerates until the final height is reached. The trunk diameter increases about $2 \mathrm{~cm}$ per year (Barwick 2004; Elevitch 2006).

Field measurements

The field measurements of the structural parameters of C. nucifera were carried out in Omu and Bulili while data collection of A. moluccana and G. sepium was conducted around Bulili only. 23 A. moluccana trees, 28 G. sepium trees and $41 C$. nucifera trees (20 in Omu and 21 in Bulili) standing as shade trees in cacao agroforestry stands were selected and surveyed. The selection was random among the directly accessible trees and only trees with a trunk height larger than $1.3 \mathrm{~m}$ were selected. Tree structural parameters such as dbh, tree height, trunk height (refers to the height of the crown base), crown length (tree height minus trunk height) and crown radii were measured. Because of species-specific morphological differences, trunk height was defined for each tree species respectively. For A. moluccana, trunk height is defined as height, where on average the foliage starts; whereas for $C$. nucifera and G. sepium, trunk height is defined as base height of the first foliated branch or frond. Tree diameter was measured at $1.3 \mathrm{~m}$ above the ground using a metric diameter measuring tape. It should be emphasised that even though the exclusion of small trees ( $<1.3 \mathrm{~m}$ trunk height) limits the range of the derived allometric functions, it does not limit the applicability of the results of the study as the study deals with shade trees that are able to provide shade for cacao after they reach a certain height. Tree height, trunk height and crown length measurements were taken according to the trigonometric principle with a Vertex IV ultrasonic hypsometer and appropriate transponder T3. Crown radius measuring was conducted as the vertical alignment of crown projection recorded in eight directions via 'Kronenspiegel-Densiometer' (Röhle and Huber 1985).

\section{Allometric analysis}

For the determination of allometric relationships, a correlation analysis (based on the Pearson's coefficient) was carried out for all variables $(P<0.05$, with significance level of Type I error $\alpha=0.05)$. The variable abbreviations are: dbh, $\mathrm{DBH}(\mathrm{cm})$; height, $\mathrm{H}$ (m); trunk height, TH (m); crown length, CL (m) and crown radius, $\mathrm{CR}(\mathrm{m})$. With variables, for which the significant correlation coefficient indicated a linear relationship, a regression analysis was performed. The assumptions of normality and homogeneity of residual variances were tested with the Shapiro-Wilk's test and Levene's test, respectively. The test results confirmed that the requirements are fulfilled.

As it was already mentioned in the introduction, the main focus of the study was to find relationships 
between easy and difficult measurable tree characteristics to facilitate field measurements of tree structural parameters. Therefore, the easily measurable variables $\mathrm{DBH}, \mathrm{H}$, or CL were chosen as independent variables for the analysis.

To check whether the obtained (i.e. significant) allometric functions can be applied to other plantations, an analysis of covariance (ANCOVA) combined with a test of homogeneity of slopes (HoS) was applied. The assumed null-hypothesis $\left(\mathrm{H}_{0}\right.$ total $)$ is: different study sites have regression lines with similar slopes; hence, the allometric functions are transferable. The null-hypotheses were tested at a $5 \%$-level. The ANCOVA was performed both for the present data and for the inventory data of studies conducted in Kecamatan Kulawi and Kecamatan Palolo. Within the ANCOVA, two different tests were performed. While the first test was used to verify whether the relationships between tree structural parameters found during this study are similar the results of other studies, the second test tried to find out whether there is a difference between mean values of the parameters obtained at different study sites. The first test was focused on the slopes of the regression lines. It was examined whether one structural parameter (covariate), e.g. dbh, has an effect on another tree structural parameter (dependent variable), e.g. height. Thus, the first $\mathrm{H}_{0}$ (ANCOVA1) reads: the covariate has no effect on the dependent variable. The second test addressed the intercepts, so the respective $\mathrm{H}_{0}$ (ANCOVA2) reads 'there are no differences between the study sites'. The HoS of the regression lines was performed to examine whether the regression lines of all study sites have the same slope. $\mathrm{H}_{0}$ (HoS) reads 'both regression lines have the same slope'. Subsequently the intercepts and slopes of the regression lines were calculated and illustrated in scatter plots.

\section{Results and discussion}

\section{Tree structural characteristics}

Table 1 summarizes the tree structural characteristics and their variability of the investigated shade tree species A. moluccana, C. nucifera and G. sepium. The 'range of application' describes minimal and maximal values of the measured parameter, and, thus, the limits within which the derived functions are applicable.
For all three shade tree species, the measurements cover a comparatively broad range of dbh classes, which are above the size from which on the tree is able to serve as a shade one. When interpreting those results, attention should be paid to the fact that A. moluccana and G. sepium are dicotyledonous trees. Thus, no growth of trunk height, which is the height from the ground to the lowest branch (also called 'crown base height'), takes place as dicotyledonous trees posses an apical growth that proceeds at the terminal buds. The only natural way that the trunk height could increase is if self-pruning takes place. However, the process of self-pruning constitutes a negligibly minor part. Dbh, height, crown length and crown radius might increase continuously. The increment of dbh depends on the secondary growth in girth of the stem, whereas the increment of the other parameters is dependent on the apical growth (Hocher et al. 2005). On the contrary, C. nucifera, as all palms, is monocotyle, implying that no secondary growth in girth takes place; the trunk diameter is predetermined by the apical meristem (von Martius 1846; Lotschert 1985; Elevitch 2006). Therefore, it shows a completely different growth pattern than A. moluccana and $G$ sepium. In all three cases, the overview of the investigated tree structural parameters gives a hint about their morphological appearance. Morphological considerations can be made regarding the trunk-crown ratio and the crown radius-crown length ratio. The proportion of trunk to crown for A. moluccana is $1: 4$ and its crown has a ratio of 1:3 radius to length (Table 1). For C. nucifera, the proportion of trunk to crown changes over the years, e.g. 1:1 for younger palms in Bulili and 2:1 for older palms in Omu. The crown of $C$. nucifera has a 1:2 radius to length ratio. The proportion of trunk to crown for G. sepium is 2:3 and the ratio of the crown is $1: 2$ radius to length. Regarding the minimum and maximum measured dbhs and the corresponding heights (Table 1) a statement about the growth rate of the dicotyledonous species can be made. As for A. moluccana, the minimum dbh of the measured individuals is around $14 \mathrm{~cm}$ and the maximum dbh around $52 \mathrm{~cm}$ whereas the corresponding heights are around 8 and $25 \mathrm{~m}$, respectively. This indicates a moderately fast growth that corresponds to the results of Elevitch (2006). The measured G. sepium individuals have a minimum $\mathrm{dbh}$ of around $7 \mathrm{~cm}$ and a maximum dbh of around $44 \mathrm{~cm}$ with corresponding heights of around 7 and $13 \mathrm{~m}$ that 
Table 1 Structural characteristics of studied shade trees Aleurites moluccana, Cocos nucifera and Gliricidia sepium

\begin{tabular}{|c|c|c|c|c|c|c|c|c|c|}
\hline & \multicolumn{3}{|c|}{ Aleurites moluccana } & \multicolumn{3}{|c|}{ Cocos nucifera } & \multicolumn{3}{|c|}{ Gliricidia sepium } \\
\hline & Mean & SD & Range of application & Mean & $\mathrm{SD}$ & Range of application & Mean & SD & Range of application \\
\hline $\mathrm{dbh}(\mathrm{cm})$ & 34.8 & 12.3 & $14.1 / 51.6$ & 31.0 & 4.6 & $19.2 / 40.9$ & 20.4 & 11.0 & $7.0 / 44.1$ \\
\hline Height (m) & 14.5 & 4.7 & $7.9 / 25.2$ & 21.5 & 5.6 & $13.2 / 38.1$ & 10.3 & 1.5 & $7.3 / 12.9$ \\
\hline Trunk height (m) & 2.8 & 1.3 & $1.2 / 6.4$ & 13.1 & 4.8 & $6.0 / 24.0$ & 3.6 & 0.8 & $2.1 / 5.7$ \\
\hline Crown length (m) & 11.7 & 4.6 & $5.3 / 22.0$ & 8.4 & 2.4 & $3.5 / 14.1$ & 6.6 & 1.6 & $2.5 / 9.3$ \\
\hline Crown radius $(\mathrm{m})$ & 4.4 & 1.4 & $2.5 / 7.4$ & 4.4 & 0.8 & $2.5 / 6.1$ & 2.9 & 0.8 & $1.2 / 5.1$ \\
\hline
\end{tabular}

The data of Cocos nucifera are pooled data of the stands in Omu and Bulili, whereas the data of Aleurites moluccana and Gliricidia sepium are of the stand in Bulili

points to a fast growth that goes along with the results of Elevitch (2006) and Barwick (2004).

\section{Allometric relationships}

We would like to emphasise that the obtained relationships, described in this chapter, are valid for their respective range of application (Table 1) only (Fang and Bailey 1998). Standard tree height curves and many other allometric relationships are nonlinear (Widlowski et al. 2003): they start from the origin of coordinates, are steeper for smaller trees, and flatten for larger trees. In the present study, only 'matured' shade trees were measured as these are high enough (Table 1) to be able to provide shade for cacao trees. Thus, the obtained linear allometric relationships are valid for trees from a rather flat linear section of the curve, and therefore, the presented allometric functions do not start from the coordinate origin.

Six significant correlations between four structural parameters dbh, height, crown length, and crown radius are observed for the dicotyledonous tree species A. moluccana and G. sepium.

The crown radius of mature G. sepium trees is strongly affected by tending practices, namely by lateral pruning. Such correctional prunings are common practice in cacao agroforestry systems aimed to reduce light competition for T. cacao (Elevitch 2006). Farmers cut off branches whereas the degree of cutting depends on the size of the tree's crown and surrounding crowns, i.e. the competitive situation on place. This implies that cutting depends on the subjective opinion of farmers. The effect is illustrated in Fig. 1 where the crown radius decreases after a dbh of about $20 \mathrm{~cm}$, as from this point, lateral pruning of the crown usually takes place. Such pruning effects could be approximated by a quadratic function as done here.
However, this function is not generally applicable, and it is not advisable to use it for other plantation, as pruning practises vary greatly among farmers. Still it is possible to derive an allometric dependence for the 'natural' not-pruned phase of G. sepium trees, i.e. for smaller trees. Thus, G. sepium trees within a dbh range of 7-20.1 cm are used to derive linear relationships between crown radius and $\mathrm{dbh}$, height and crown length, respectively (Fig. 2).

For the monocotyledonous palm, C. nucifera, three significant correlations are found whereas length parameters as height and trunk height correlate with each other respectively and those parameters, which are predetermined by the apical meristem, e.g. dbh and crown radius (Fig. 2). The corresponding elements of the equations are summarized in Table 2 and 3.

For A. moluccana and C. nucifera, all relationships can be described as linear ones as well as most of the relationships of G. sepium (Table 2). The exceptions for G. sepium are the dependencies dbh-height and

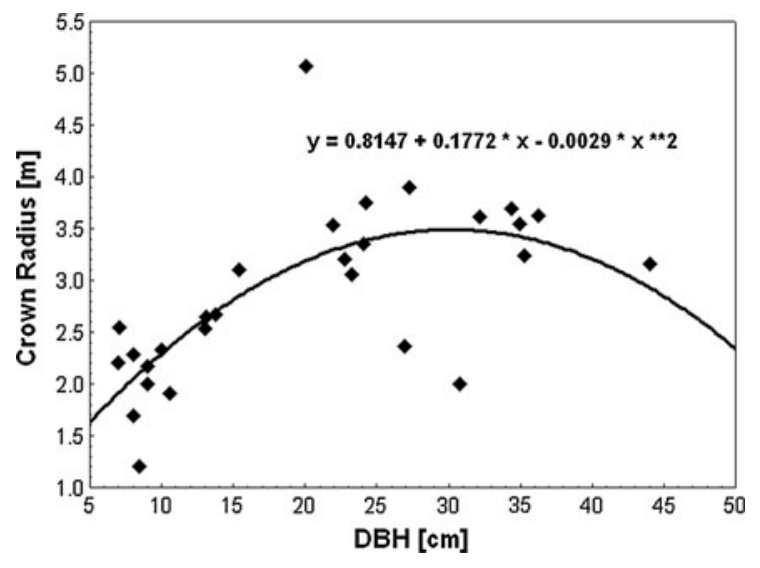

Fig. 1 Relationship between DBH (cm) and CR (m) for pruned and non-pruned trees of Gliricidia sepium 
Fig. 2 Significant $(P<0.005)$ correlations of the tree structural parameters DBH, $H, \mathrm{TH}, \mathrm{CL}$ and $\mathrm{CR}(\mathrm{m})$ for the shade tree species Aleurites moluccana, Cocos nucifera and Gliricidia sepium

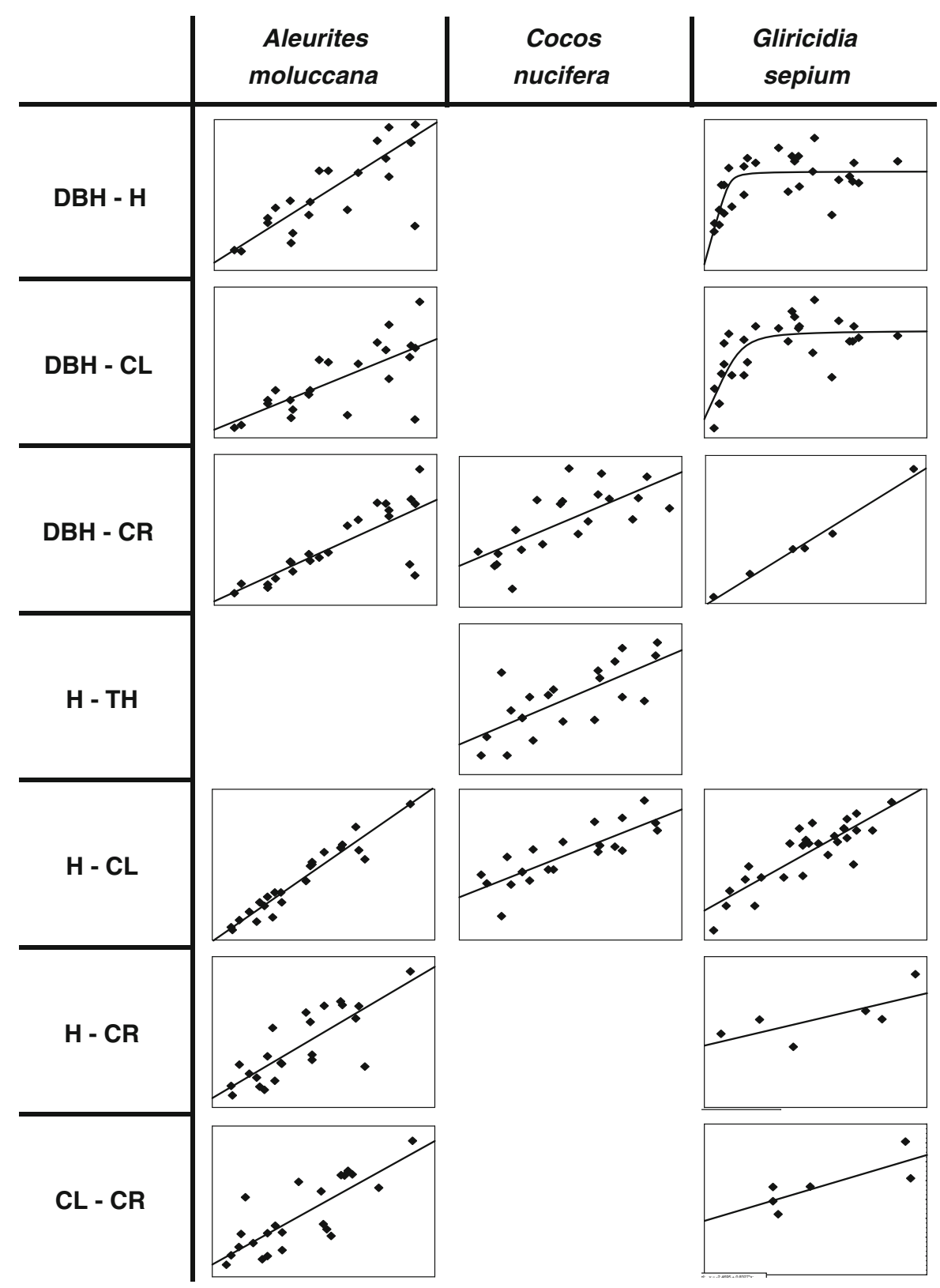

dbh-crown length, which follow a logistic trend (Table 3). To describe both non-linear relationships for G. sepium, the attempt was made to apply standard growth functions, which are commonly used in forestry. The one with the best fit in terms of multiple correlation coefficients was chosen in both cases, namely a non-rectangular hyperbola (Thornley 1976). The best fit of the functions was achieved with the maximum height fixed at $11 \mathrm{~m}$ and the mean crown length at $8 \mathrm{~m}$, respectively, which agrees well with the observed data and the literature values. Thus, Elevitch (2006) state that $G$. sepium typically reaches a height of $10 \mathrm{~m}$, although it can grow up to $15 \mathrm{~m}$ occasionally and Simons and Stewart (Simons and Stewart 1998) mention that it usually grows up to $10-12 \mathrm{~m}$. The results also agree with the funding of Koehler et al. (Köhler et al. 2009) who measured a mean height of $10.9 \pm 2.1 \mathrm{~m}$ for 18 trees of a cacao agroforestry stand in the neighbouring village Marena (app. $5 \mathrm{~km}$ south from Kulawi). 
Table 2 Linear relationships ( $y=a+b \times x)$ of tree structural parameters DBH (cm), H, TH, CL and CR (m) of shade tree species Aleurites moluccana, Cocos nucifera and Gliricidia sepium with corresponding coefficient of determination $\left(r^{2}\right)$ and $P$ value

\begin{tabular}{|c|c|c|c|c|c|c|c|c|}
\hline & Dependent variable & Independent variable & a & $\mathrm{SE}_{\mathrm{a}}$ & $\mathrm{b}$ & $\mathrm{SE}_{\mathrm{b}}$ & $r^{2}$ & $P$ value \\
\hline \multirow[t]{6}{*}{ Aleurites moluccana } & $H$ & DBH & 3.6784 & 1.858 & 0.3101 & 0.050 & 0.643 & 0.000 \\
\hline & $\mathrm{CL}$ & DBH & 2.4065 & 2.104 & 0.2673 & 0.057 & 0.510 & 0.000 \\
\hline & $\mathrm{CR}$ & DBH & 1.2577 & 0.573 & 0.0898 & 0.016 & 0.613 & 0.001 \\
\hline & $\mathrm{CL}$ & $H$ & -1.7558 & 0.877 & 0.9306 & 0.058 & 0.925 & 0.000 \\
\hline & CR & $H$ & 0.9461 & 0.589 & 0.2376 & 0.039 & 0.643 & 0.000 \\
\hline & $\mathrm{CR}$ & CL & 1.5061 & 0.502 & 0.2457 & 0.040 & 0.643 & 0.000 \\
\hline \multirow[t]{2}{*}{ Cocos nucifera } & $\mathrm{TH}$ & $H$ & 1.5896 & 1.649 & 0.4173 & 0.092 & 0.521 & 0.000 \\
\hline & CL & $H$ & -1.5896 & 1.649 & 0.5827 & 0.092 & 0.663 & 0.000 \\
\hline \multirow[t]{4}{*}{ Gliricidia sepium } & $\mathrm{CR}$ & DBH & -1.6420 & 0.300 & 0.3242 & 0.021 & 0.983 & 0.000 \\
\hline & CL & $H$ & -3.0425 & 1.142 & 0.9436 & 0.110 & 0.738 & 0.000 \\
\hline & CR & $H$ & -4.6245 & 3.524 & 0.6947 & 0.329 & 0.527 & 0.100 \\
\hline & $\mathrm{CR}$ & CL & -2.4695 & 2.087 & 0.8327 & 0.327 & 0.619 & 0.063 \\
\hline
\end{tabular}

Table 3 Logistic dependencies $\left(y=0.5 \times\left(a \times x+b-\sqrt{\left((a \times x+c)^{2}-4 \times a \times x \times b\right)}\right)\right)$ of tree structural parameters DBH $(\mathrm{cm}), \mathrm{H}$ and CL $(\mathrm{m})$ of Gliricidia sepium with corresponding multiple correlation coefficient $(r)$

\begin{tabular}{lllrrrr}
\hline & Dependent variable & Independent variable & $a$ & $b$ & $c$ & $r$ \\
\hline Gliricidia & $H$ & DBH & 1.0901 & 10.9410 & 11.0 \\
Sepium & CL & DBH & 0.6430 & 7.8051 & 8.0 & 0.7722 \\
\hline
\end{tabular}

For A. moluccana, trunk height does not correlate with any of the investigated parameters, because it is, as stated above, a dicotyledonous tree species and its trunk height without self-pruning remains the same, whereas the other parameters increases continuously. In this study, the correlation and regression analyses of the allometric relationship between dbh and height of A. moluccana indicated a linear dependency, which is not common for height curves. Usually, they show a point of culmination; this is where the maximum height of the tree is reached and the height does not increase anymore. The position of the culmination point depends on the growth rate of species as fast growing tree species have an earlier point of culmination than slow growing ones (Kramer 1988). A possible reason for the linearity might be that in this study mainly tree heights around or below the point of culmination were measured, so that the collected data represent the linear part of the height curve. The same applies to the relation of dbh and crown length, as the increment of height is directly dependent on the apical growth of the crown length. Thus, the height increases if the crown length grows. This is likewise the explanation for the very good fit $\left(r^{2}=0.925\right)$ of the linear relation between height and crown length. The relation of $\mathrm{dbh}$ and crown radius is commonly agreed to be linear (Dawkins 1963), which is also observed in this study. This, again, is explained by the growth characteristics of dicotyledonous trees, whereas the size of the crown radius is largely influenced by stand density due to the competition for light. Height, crown length, and crown radius correlate with each other respectively as their increment is depend on the apical growth.

Because of monocotyledonism of C. nucifera dbh, crown length and crown radius remain almost constant as mentioned above. Thus, only few correlations between structural parameters could be found and, therefore, few allometric functions could be derived. The correlation of dbh and crown radius is explained by the fact that both $\mathrm{dbh}$ and crown radius are predetermined by the apex of $C$. nucifera. However, it is not classified as allometric relationship, in contrast to all other significant correlations of this study, which are graded as dynamic functions. Dbh and crown radius stay steady at each age and do not increase 
Fig. 3 Transferability of derived allometric relationships to other plantations for the shade tree species Aleurites

moluccana, Cocos nucifera and Gliricidia sepium with $\mathrm{DBH}(\mathrm{cm}), H, \mathrm{TH}, \mathrm{CL}$ and $\mathrm{CR}(\mathrm{m})$. Functions are illustrated within their respective ranges of application, and thus do not include the axis origin

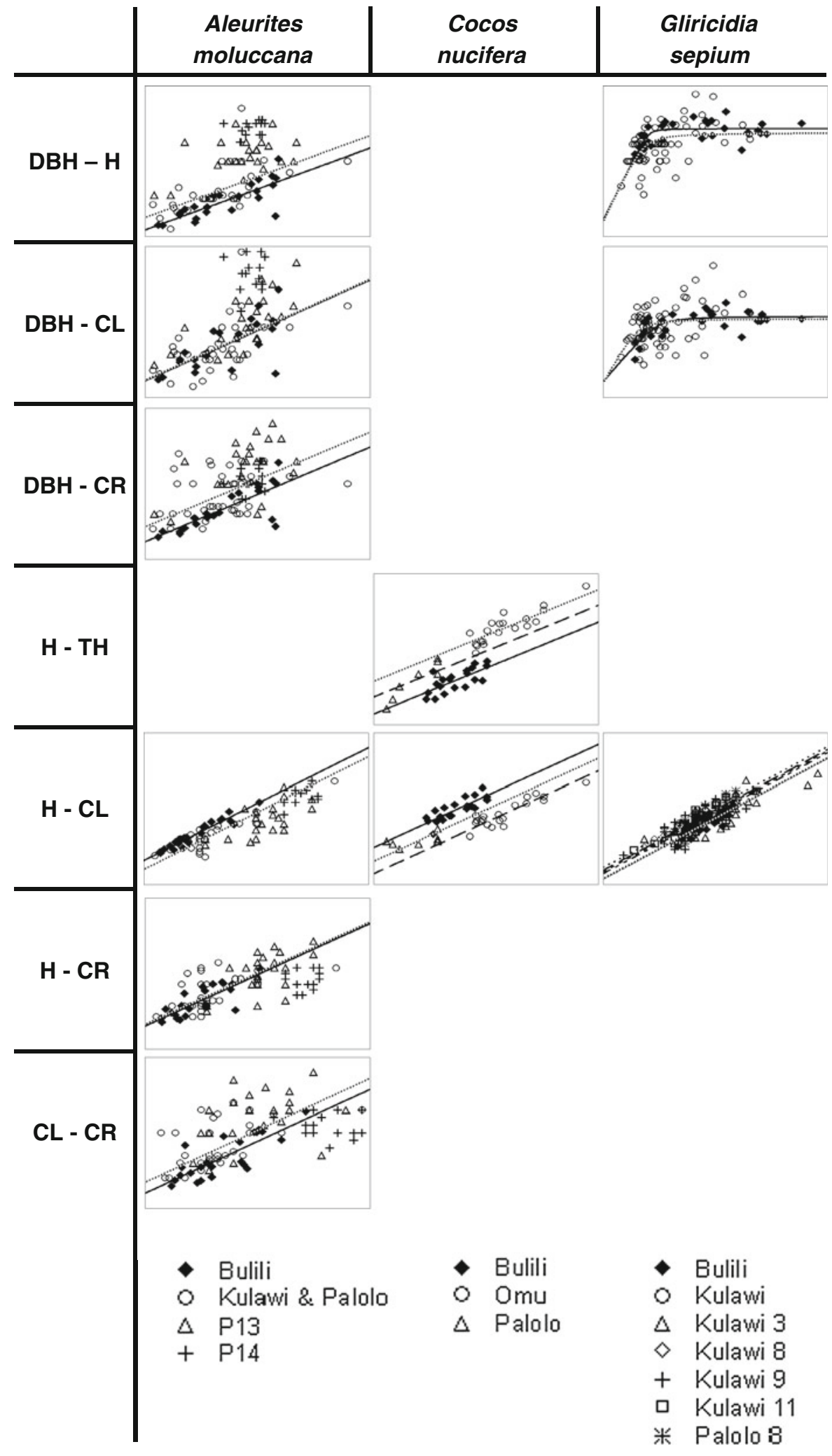


Table 4 Parameters of the allometric relationships of Aleurites moluccana, Cocos nucifera and Gliricidia sepium at different plantations and their corresponding standard errors, $P$ values and confidential limits

\begin{tabular}{|c|c|c|c|c|c|c|c|}
\hline & & \multirow[t]{2}{*}{ Site } & \multirow[t]{2}{*}{$a$} & \multirow[t]{2}{*}{$\mathrm{SE}_{\mathrm{a}}$} & \multirow[t]{2}{*}{$P$ value } & \multicolumn{2}{|c|}{ Conf. limit } \\
\hline & & & & & & Lower & Upper \\
\hline \multirow[t]{12}{*}{ Aleurites moluccana } & \multirow[t]{2}{*}{$\mathrm{DBH}-H$} & Bulili & 3.6784 & 0.591 & 0.000 & 2.452 & 4.905 \\
\hline & & Kulawi \& Palolo & 7.0309 & 0.822 & 0.000 & 5.361 & 8.701 \\
\hline & \multirow[t]{2}{*}{$\mathrm{DBH}-C L$} & Bulili & 2.4065 & 0.670 & 0.002 & 1.017 & 3.796 \\
\hline & & Kulawi \& Palolo & 2.6114 & 0.699 & 0.001 & 1.191 & 4.032 \\
\hline & \multirow[t]{2}{*}{$\mathrm{DBH}-C R$} & Bulili & 1.2577 & 0.183 & 0.000 & 0.879 & 1.636 \\
\hline & & Kulawi \& Palolo & 2.2680 & 0.266 & 0.000 & 1.727 & 2.809 \\
\hline & \multirow[t]{2}{*}{$H-\mathrm{CL}$} & Bulili & -1.7558 & 0.262 & 0.000 & -2.299 & -1.213 \\
\hline & & Kulawi \& Palolo & -4.6380 & 0.426 & 0.000 & -5.503 & -3.773 \\
\hline & \multirow[t]{2}{*}{$H-\mathrm{CR}$} & Bulili & 0.9461 & 0.176 & 0.000 & 0.582 & 1.310 \\
\hline & & Kulawi \& Palolo & 1.1352 & 0.224 & 0.000 & 0.680 & 1.590 \\
\hline & \multirow[t]{2}{*}{$\mathrm{CL}-\mathrm{CR}$} & Bulili & 1.5061 & 0.175 & 0.000 & 1.142 & 1.870 \\
\hline & & Kulawi \& Palolo & 2.4290 & 0.219 & 0.000 & 1.984 & 2.874 \\
\hline \multirow[t]{6}{*}{ Cocos nucifera } & \multirow[t]{3}{*}{$H-\mathrm{TH}$} & Bulili & 1.5896 & 0.268 & 0.000 & 1.030 & 2.149 \\
\hline & & $\mathrm{Omu}$ & 6.7897 & 0.273 & 0.000 & 6.219 & 7.360 \\
\hline & & Palolo & 4.2739 & 0.554 & 0.000 & 2.963 & 5.584 \\
\hline & \multirow[t]{3}{*}{$H-\mathrm{CL}$} & Bulili & -1.5896 & 0.268 & 0.000 & -2.149 & -1.030 \\
\hline & & $\mathrm{Omu}$ & -6.7897 & 0.273 & 0.000 & -7.360 & -6.219 \\
\hline & & Palolo & -4.2739 & 0.554 & 0.000 & -5.584 & -2.963 \\
\hline \multirow[t]{6}{*}{ Gliricidia sepium } & \multirow[t]{6}{*}{$H-\mathrm{CL}$} & Bulili & -3.0425 & 0.159 & 0.000 & -3.368 & -2.717 \\
\hline & & Kulawi 3 & -2.9325 & 0.219 & 0.000 & -3.374 & -2.491 \\
\hline & & Kulawi 8 & -1.0544 & 0.112 & 0.000 & -1.296 & -0.813 \\
\hline & & Kulawi 9 & -1.8110 & 0.207 & 0.000 & -2.227 & -1.395 \\
\hline & & Kulawi 11 & -2.1316 & 0.169 & 0.000 & -2.476 & -1.788 \\
\hline & & Palolo 8 & -1.5681 & 0.311 & 0.000 & -2.221 & -0.916 \\
\hline \multirow[t]{8}{*}{ Gliricidia sepium (logistic) } & \multirow[t]{4}{*}{$\mathrm{DBH}-H$} & Bulili & 1.0901 & 0.080 & 0.000 & 0.926 & 1.254 \\
\hline & & b (Bulili) & 10.9410 & 0.082 & 0.000 & 10.773 & 11.109 \\
\hline & & Kulawi & 1.1904 & 0.169 & 0.000 & 0.854 & 1.527 \\
\hline & & b (Kulawi) & 10.6120 & 0.188 & 0.000 & 10.237 & 10.987 \\
\hline & \multirow[t]{4}{*}{$\mathrm{DBH}-\mathrm{CL}$} & Bulili & 0.6430 & 0.069 & 0.000 & 0.501 & 0.786 \\
\hline & & b (Bulili) & 7.8051 & 0.116 & 0.000 & 7.568 & 8.043 \\
\hline & & Kulawi & 0.9828 & 0.220 & 0.000 & 0.543 & 1.423 \\
\hline & & b (Kulawi) & 7.6218 & 0.193 & 0.000 & 7.237 & 8.007 \\
\hline
\end{tabular}

once they are formed. The linearity of the relation is assumed, since the literature evidence of contrary could not be detected. The relation of height and trunk height shows a fit of $r^{2}=0.521$, as the height of the palms depends almost exclusively on the trunk height. The good correlation between height and crown length $r^{2}=0.663$ is unexpected, as it does not correspond to the monocotyledonous growth pattern of $C$. nucifera and such a relationship could not be detected in the literature. The implemented standard methodology and high accuracy of measurements allow to accept the measurement results as appropriate and the derived functions as valid for the investigated palms. Further research on that topic is advisable.

Even though G. sepium is also a dicotyledonous tree species, it shows partly other growth patterns than 
A. moluccana. Here, too, it is observed that there is no correlation of trunk height with any of the other investigated parameters, but the relation of $\mathrm{dbh}$ and height and dbh and crown length is rather a logistic than a linear one (see above). This is because $G$. sepium is a fast growing tree species (Barwick 2004; Elevitch 2006). During the first growth periods, the growth in length is rapid so that the point of culmination is reached early. Henceforth, the growth rate decreases, whereas the growth in girth intensifies (Kramer 1988; Lamprecht 1989). Both relationships show a similar fit, since the growth of height is dependent on the apical growth of the crown length, which is as well the explanation for the good fit $\left(r^{2}=0.738\right)$ of the linear relation height and crown length. The linear relationships between $\mathrm{dbh}$ and crown radius $\left(r^{2}=0.983\right)$, height and crown radius $\left(r^{2}=0.527\right)$, and crown length and crown radius $\left(r^{2}=0.619\right)$ are estimated for the dbh range $7-20.1 \mathrm{~cm}$.

\section{Site effects and transferability}

Fig. 3 illustrates the transferability of the derived allometric relationships to other plantations in Kulawi and Palolo. For all relationships that are shown here, except for the logistic ones, applies that both nullhypotheses of the ANCOVA $\left(\mathrm{H}_{0}\right.$ (ANCOVA1) and $\mathrm{H}_{0}$ (ANCOVA2) are rejected with $P<0.05$, saying that the covariate has an effect on the dependent variable $\left(\mathrm{H}_{1}\right.$ (ANCOVA1) and that there are differences between the study sites $\left(\mathrm{H}_{1}\right.$ (ANCOVA2) $)$. Furthermore, the nullhypothesis of $\mathrm{HoS}\left(\mathrm{H}_{0}(\mathrm{HoS})\right.$ is accepted with $P>0.05$, implying that both regression lines have the same slope $\left(\mathrm{H}_{1(\mathrm{HoS})}\right)$. Altogether, it says that on all study sites, there is the same dependency between two variables despite of potentially varying site conditions and that the dependency is aligned within all study sites. Therefore, the overall null-hypothesis $\left(\mathrm{H}_{0 \text { total }}\right)$ is accepted; the allometric functions are transferable. For the logistic dependencies applies that the ranges of the $95 \%$ confidence intervals of the parameters $a$ and $b$ of Bulili and Kulawi are overlapping respectively, denoting that the functions are not unequal, i.e. they are similar (Table 4). Hence, the allometric functions are transferable.

The comparison of the investigated dataset with datasets of other studies in Palolo and Kulawi, shows that most of the obtained allometric functions are transferable to other plantations of the region, even if the site conditions, as soil fertility, water availability et cetera, differ. Exceptions are the relationships of crown radius with dbh, height and crown length for $G$. sepium, which are not transferable to other sites, i.e. Palolo and Kulawi. The most probable reason is the effect of pruning, which is the main tending procedures for G. sepium, and which directly influences the size of the crown radius. The valleys of Palolo and Kulawi have a high proportion of migrants, varying inexperience with agroforestry management of which have an effect on the cultivation and tending techniques (e.g. pruning practises) (Faust et al. 2003). Thus, it could be safely assumed that pruning was carried out differently at different plantations, influencing the crown radius of G. sepium trees in a different manner. That of course complicates the transferability of allometric functions for crown radius.

In case of A. moluccana, the mean height of two plantations, Palolo 13 and Palolo14 (Fig. 3), differ clearly from all other plantations. It can be seen that in Palolo 14 all trees are well grown (about $35 \mathrm{~m}$ ) and have almost the same dbh and height. A possible explanation could be that those shade trees are naturally grown rainforest remnants (see Sect. 2.1), which has grown under the conditions of intensive competition for light, and which are therefore much higher than artificially planted shade trees of similar dbh. For those two plantations, the allometric functions derived in this study are not applicable.

\section{Conclusion}

Revealing species-specific allometric relationships, this study provides important basics for the description of shade tree structure of A. moluccana, C. nucifera and G. sepium that is required in experimental and modelling studies dealing with ecosystem processes in cacao agroforestry systems such as nutrient cycling, radiative transfer, wind regime and hydrological cycling. Furthermore, it shows that most of the derived allometric functions are applicable to other cacao agroforestry systems of that region. However, we would like to emphasise that the obtained functions should be applied with caution to other sites. The adjustment of the functions (intercept calibration) has to be carried out under the consideration of tree age and establishment method, i.e. whether agroforestry 
plantations are based on rainforest remnants or planted shade trees. Further investigations are needed that compare the structural development of natural and planted shade trees. Still, this study does contribute to a better description and understanding of cacao agroforestry systems and the species-specific information contribute to the enhancement of knowledge about growth and development of the investigated tree species. Thus, this study provides useful information and a tool for the assessment and management of cacao agroforestry systems. The derived dependencies between structural parameters of shade trees can facilitate fieldwork in cacao agroforestry systems aimed at the estimation of tree structural parameters to provide a base for process-based ecosystem and yield modelling. Further research should be implemented to extend the knowledge on agroforestry systems by obtaining information on the same tree species from other regions and by measuring structural properties of other main shade tree species.

Acknowledgment We highly acknowledge the financial support of Konrad-Krieger-Stiftung and the contribution of Yann Clough and Ramadhanil Pitopang for providing inventory datasets of the region.

Open Access This article is distributed under the terms of the Creative Commons Attribution License which permits any use, distribution, and reproduction in any medium, provided the original author(s) and the source are credited.

\section{References}

Alpízar L, Fassbender HW, Heuveldop J, Fölster H, Enriquez G (1986) Modelling agroforestry systems of cacao (Theobroma cacao) with laurel (Cordia alliodora) and poro (Erythrina poeppigiana) in Costa Rica. I. Inventory of organic matter and nutrients. Agrofor Syst 4:175-189

Barwick M (2004) Tropical and subtropical trees-an encyclopedia. Timber Press, Portland

Beer JW (1987) Advantages, disadvantages and desirable characteristics of shade trees for coffee, cacao and tea. Agrofor Syst 5:3-13

Beer JW, Bonnemann A, Chavez W, Fassbender HW, Imbach AC, Martel I (1990) Modelling agroforestry systems of cacao (Theobroma cacao) with laurel (Cordia alliodora) and poro (Erythrina poeppigiana) in Costa Rica. V. Productivity indices, organic material models and sustainability over 10 years. Agrofor Syst 12:229-249

Bhagwat SA, Willis KJ, Birks JB, Whittaker RJ (2008) Agroforestry: a refuge for tropical biodiversity? Trends Ecol Evol 23:261-267
Chen J-W, Zhang Q, Li XS, Cao KF (2009) Independence of stem and leaf hydraulic traits in six Euphorbiaceae tree species with contrasting leaf phenology. Planta 230(3):459-468

Clough Y, Dwi Putra D, Pitopang R, Tscharntke T (2009) Local and landscape factors determine functional bird diversity in Indonesian cacao agroforestry. Biol Conserv 142:10321041

Cole TG, Ewel JJ (2006) Allometric equations for four valuable tropical tree species. Forest Ecol Manag 229:351-360

Dauzat J, Eroy MN (1997) Simulating light regime and intercrop yields in coconut based farming systems. Eur J Agron 7:63-74

Dawkins HC (1963) Crown diameters: their relation to bole diameter in tropical forest trees. Commonw Forest Rev 42:318-333

Direktorat Hutan Tanaman Industri (1990) Teknik Pembuatan Tanaman Kemiri

Dudley NS, Fownes JH (1992) Preliminary biomass equations for eight species of fast-growing tropical trees. J Trop Sci 5:68-73

Elevitch CR (2006) Traditional trees of Pacific Islands: their culture, environment, and use. Permanent agriculture resources (PAR), Hōlualoa, United States of America

Fang Z, Bailey RL (1998) Height-diameter models for tropical forests on Hainan Island in southern China. Forest Ecol Manag 110:315-327

FAO (2004) National Forest Inventory Field Manual Template. FAO Working Paper 94/E. United Nations Food and Agriculture Organisation, Rome, Italy

Fassbender HW, Alpízar L, Heuveldop J, Fölster H, Enriquez G (1988) Modelling agroforestry systems of cacao (Theobroma cacao) with laurel (Cordia alliodora) and poro (Erythrina poeppigiana) in Costa Rica. III. Cycles of organic matter and nutrients. Agrofor Syst 6:49-62

Faust H, Maertens M, Weber R, Nuryartono N, van Rheenen T, Birner R (2003) Does migration lead to destabilization of forest margin areas? Evidence from an interdisciplinary field study in Central Sulawesi. Göttingen, Bogor. STORMA Discussion Paper Series Sub-Program A, No. 11

Fuwape JA, Onyekwelu JC, Adekunle VAJ (2001) Biomass equations and estimation for Gmelina arborea and Nauclea diderrichii stands in Akure forest reserve. Biomass Bioenerg 21:401-405

Henderson A (2009) Palms of Southern Asia. The New York Botanical Garden, New York

Hocher V, Verdeil JL, Malaurie B (2005) Cocos nucifera coconut. In: Litz RE (ed.) Biotechnology of fruit and nut crops: 4.1 Arecaceae. Biotechnology in Agriculture Series 29: $90-112$

Imbach AC, Fassbender HW, Borel R, Beer J, Bonnemann A (1989) Modelling agroforestry systems of cacao (Theobroma cacao) with laurel (Cordia ailiodora) and poro (Erythrina poeppigiana) in Costa Rica. IV. Water balances, nutrient inputs and leaching. Agrofor Syst 8:267-287

Isaac ME, Timmer VR, Quashie-Sam SJ (2007) Shade tree effects in an 8 year-old cocoa agroforestry system: biomass and nutrient diagnosis of Theobroma cacao by vector analysis. Nutr Cycl Agroecosys 78:155-165

Jose S (2009) Agroforestry for ecosystem services and environmental benefits: an overview. Agrofor Syst 76:1-10 
Köhler M, Dierick D, Schwendenmann L, Hölscher D (2009) Water use characteristics of cacao and Gliricidia trees in an agroforest in Central Sulawesi, Indonesia. Ecohydrology 2:520-529

Kramer H (1988) Waldwachstumslehre: ökologische und anthropogene Einflüsse auf das Wachstum des Waldes, seine Massen-und Wertleistung und die Bestandessicherheit. Verlag Paul Parey, Hamburg and Berlin

Lamanda N, Dauzat J, Jourdan C, Martin P, Malézieux M (2008) Using $3 \mathrm{D}$ architectural models to assess light availability and root bulkiness in coconut agroforestry systems. Agrofor Syst 72:63-74

Lamprecht H (1989) Silviculture in the tropics: tropical forest ecosystems and their tree species: possibilities and methods for their long-term utilization. Dt. Ges. für Techn, Zusammenarbeit (GTZ) GmbH

Le Roux, Sinoquet (2000) In: Mialet-Serra I, Dauzat J, Auclair D (eds.) (2001) Using plant architectural models for estimation of radiation transfer in a coconut-based agroforestry system. Agrofor Syst 53: 141-149

Leroy C, Laurans M, Dauzat J, Sabatier S, Auclair D (2005) Simulation of light transmission under Acacia mangium Willd and Tectona grandis L. canopies and comparison with in situ measurements. In: Proceedings of International workshop on Smallholder AgroForestry Options for degraded Soils. Malang, Indonesia. International workshop on Smallholder AgroForestry Options for degraded Soils, Malang, Indonesia, 18-21

Leroy C, Sabatier S, Wahyuni NS, Barczi JF, Dauzat J, Laurans M, Auclaire D (2009) Virtual trees and light capture: a method for optimizing agroforestry stand design. Agrofor Syst 77:37-47

Lo Gullo MA, Nardini AP, Trifilo P, Salleo S (2005) Diurnal and seasonal variations in leaf hydraulic conductance in evergreen and deciduous trees. Tree Physiol 25(4):505-512

Lotschert W (1985) Palmen-Botanik, Kultur. Nutzung, Verlag Eugen Ulmer GmbH

Lundgren BO and Raintree JB (1982) Sustained agroforestry. In: Nestel B (ed.) Agricultural research for development: potentials and challenges in Asia: 37-49. ISNAR, The Hague, The Netherlands

McNeely JA, Schroth G (2006) Agroforestry and biodiversity conservation - traditional practices, present dynamics, and lessons for the future. Biodivers Conserv 15:549-554

Menon KPV, Pandalai KM (1958) The coconut palm-a monograph. Indian Central Coconut Committee Ernakulum, S. India

Mialet-Serra I, Dauzat J, Auclair D (2001) Using plant architectural models for estimation of radiation transfer in a coconut-based agroforestry system. Agrofor Syst 53: 141-149

Michon G, de Foresta H (1996) Agroforests: an original agroforestry model from smallholder farmers for environmental conservation and sustainable development. In: Ishizuka K, Hisajima S, Macer DRI (eds.) (1996) Traditional technology for environmental conservation and sustainable development in the Asian-Pacific region: 52-58, University of Tsukuba

Muñoz D, Estrada A, Naranjo E, Ochoa S (2006) Foraging ecology of howler monkeys in a cacao (Theobroma cacao) plantation in Comalcalco, Mexico. Am J Primatol 68: $127-142$
Nair PKR (1998) Directions in tropical agroforestry research: past, present, and future. Agrofor Syst 38:223-245

Orwa C, Mutua A, Kindt R, Jamnadass R, Simons A (2009) Agroforestree Database: a tree reference and selection guide version 4.0 International Centre for Research in Agroforestry (ICRAF). <www.worldagroforestry.org/af/ treedb/>

Quesada F, Somarriba E (2009) Simulating the shading patterns of tree shades using ShadeMotion 2.0. In: Rapidel B, Roupsard O, Navarro M (eds.) (2009) Modelling Agroforestry Systems. CATIE, Serie Técnica, Reuniones Técnicas 14: 167-174, Turrialba

Rice A, Greenberg R (2000) Cacao cultivation and the conservation of biological diversity. Royal swedish academy of sciences 2000. Ambio 29(3):167-173

Röhle H, Huber W (1985) Untersuchungen zur Methode der Ablotung von Kronenradien und der Berechnung von Kronengrundflächen. Forstarchiv 56:238-243

Roupsard O, Bonnefond JM, Irvine M, Bergigier P, Nouvellon Y, Dauzat J, Taga S, Hamel O, Jourdan C, Saint-André L, Mialet-Serra I, Labouisse JP, Epron D, Joffre R, Braconnier S, Rouziére A, Navarro M, Bouillet JP (2006) Partitioning energy and evapo-transpiration above and below a tropical palm canopy. Agr Forest Meteorl 139:252-268

Roupsard O, Dauzat J, Nouvellon Y, Deveau A, Feintrenie L, Saint-André L, Mialet-Serra I, Braconnier S, Bonnefond JM, Berbigier P, Epron D, Jourdan C, Navarro M, Bouillet JP (2008) Cross-validating sun-shade and 3D models of light absorption by a tree-crop canopy. Agr Forest Meteorol 148:549-564

Segura M, Kanninen M, Suárez D (2006) Allometric models for estimating aboveground biomass of shade trees and coffee bushes grown together. Agroforest Syst 68:143-150

Siebert SF (2002) From shade- to sun-grown perennial crops in Sulawesi, Indonesia: implications for biodiversity conservation and soil fertility. Biodivers Conserv 11:1889-1902

Simons AJ Stewart JL (1998) 2.2 Gliricidia sepium-a multipurpose forage tree legume. The Tropical Grassland Society of Australia Inc., St. Lucia Queensland

Somarriba E, Beer J (2011) Productivity of Theobroma cacao agroforestry systems with timber or legume service shade trees. Agrofor Syst 81(2):109-121

Stenchly K, Clough Y, Tscharntke T (2012) Spider species richness in cocoa agroforestry systems, comparing vertical strata, local management and distance to forest. Agr Ecosyst Environ 149:189-194

Stuppy W, van Welzen PC, Klinratana P, Posa MCT (1999) Revision of the genera Aleurites, Reutealis and Vernicia (Euphorbiaceae). Blumea 44:73-98

Suttie JM (2011) Gliricidia sepium (Jacq.). Food and Agriculture Organization of the United Nations (FAO). http://www.fao.org/ag/AGP/AGPC/doc/Gbase/DATA/ Pf000156.HTM. Accessed 11 January 2011

Thiollay J (1995) The role of traditional agroforests in the conservation of rain forest bird diversity in Sumatra. Conserv Biol 9:335-353

Thornley (1976): In: Ibrom A, Oltchev A, June T, Kreilein H, Rakkibu G, Ross T, Panferov O, Gravenhorst G (2008) Variation in photosynthetic light-use efficiency in a mountainous tropical rain forest in Indonesia. Tree Physiol 28: 499-508 
Tscharntke T, Clough Y, Bhagwat SA, Buchori D, Faust H, Hertel D, Hölscher D, Juhrbandt J, Kessler M, Perfecto I, Scherber C, Schroth G, Veldkamp E, Wanger TC (2011) Multi-functional shade-tree management in tropical agroforestry landscapes - a review. J Appl Ecol 48:619-629

Von Martius T (1846) Über die Morphologie der Palmen (im Auszug). Aus den Gelehrt. Anz. der k. bayer. Akad. d. Wissensch. Gütigst mitgetheilt vom Prof. Dr. Th. Martius 276-279
Widlowski JL, Verstraete MM, Pinty B, Gobron N (2003) Allometric relationships of selected European tree species. EC Joint Research Centre, Technical Report EUR 20855 EN, Ispra, Italy

Zuidema PA, Leffelaar PA, Gerritsma W, Mommer L, Anten NPR (2005) A physiological production model for cocoa (Theobroma cacao): model presentation, validation and application. Agr Syst 84:195-225 